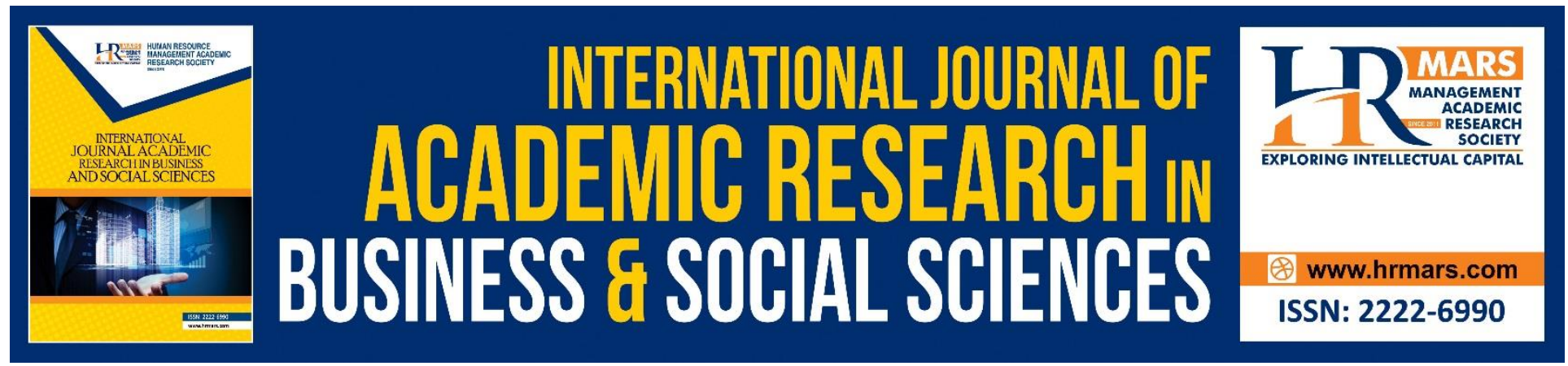

\title{
Food Security and Food Value Chain: Identifying the Influencing Components in Malaysian Seed Industry
}

Fakhrul Anwar Zainol, Chua Kim Aik, Noor Muthmainnah Hamdul Hadi, Wan Norhayate Wan Daud, Norfadzilah Rashid, Asyraf Afthanorhan

To Link this Article: http://dx.doi.org/10.6007/IJARBSS/v8-i12/5078

DOI: $10.6007 /$ IJARBSS/v8-i12/5078

Received: 14 Nov 2018, Revised: 13 Dec 2018, Accepted: 15 Dec 2018

Published Online: 30 Dec 2018

In-Text Citation: (Zainol et al., 2018)

To Cite this Article: Zainol, F. A., Aik, C. K., Hadi, N. M. H., Daud, W. N. W., Rashid, N., \& Afthanorhan, A. (2018). Food Security and Food Value Chain: Identifying the Influencing Components in Malaysian Seed Industry. International Journal of Academic Research in Business and Social Sciences, 8(12), 834-849.

Copyright: (C) 2018 The Author(s)

Published by Human Resource Management Academic Research Society (www.hrmars.com)

This article is published under the Creative Commons Attribution (CC BY 4.0) license. Anyone may reproduce, distribute, translate and create derivative works of this article (for both commercial and non-commercial purposes), subject to full attribution to the original publication and authors. The full terms of this license may be seen

at: http://creativecommons.org/licences/by/4.0/legalcode

Vol. 8, No. 12, 2018, Pg. 834 - 849

http://hrmars.com/index.php/pages/detail/IJARBSS

JOURNAL HOMEPAGE

Full Terms \& Conditions of access and use can be found at http://hrmars.com/index.php/pages/detail/publication-ethics 


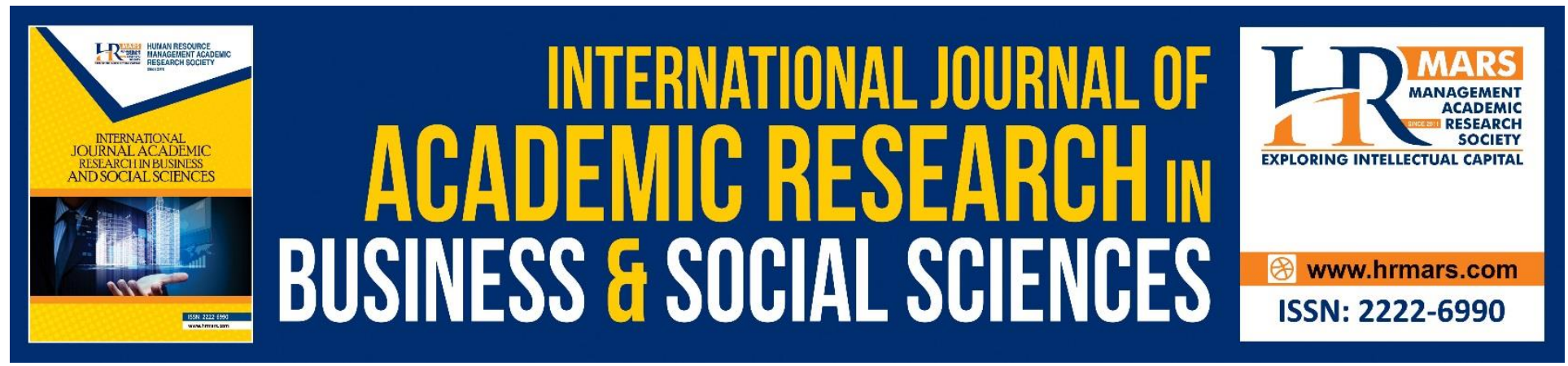

\title{
Food Security and Food Value Chain: Identifying the Influencing Components in Malaysian Seed Industry
}

\author{
${ }^{1}$ Fakhrul Anwar Zainol, ${ }^{2}$ Chua Kim Aik, ${ }^{3}$ Noor Muthmainnah \\ Hamdul Hadi, ${ }^{3}$ Wan Norhayate Wan Daud, ${ }^{4}$ Norfadzilah Rashid, \\ ${ }^{5}$ Asyraf Afthanorhan \\ 1,2,3,4,5 Faculty of Economics and Management Sciences, Universiti Sultan Zainal Abidin 21300 \\ Kuala Nerus, Terengganu, Malaysia \\ *Corresponding Author: fakhrulanwar@unisza.edu.my
}

\begin{abstract}
Food insecurity is a common problem among low-income households in developing countries, including Malaysia. To be self-sufficient and attain food security, the growing need is to produce more food from less land. This formidable challenge has been brought to the attention of all policy makers, to realize the importance of agriculture, to put emphasis on food production and declared food self-sufficiency as their strategy to attain food security. This challenge and its complex, sustainable development issue triggered changes within the agriculture industry and has promoted development of the seed industry. The emphasis is on developing high yielding seed. High quality seed is the most important input for a productive agriculture. The seed industry in Malaysia is falling behind, not well develop, and apparently still at the early phase of development. Hence, high quality seed is difficult to obtain due to a lack of participation. To develop any industry requires strategy. The seed industry has rarely been an empirical setting for research, while within this research area, the start-up of new seed industry activities is viewed as the exploitation of business opportunities. In this study, face-to-face and semi-structured interviews have been adopted. Data collected from the interviews was analyzed qualitatively using Atlas.ti version 7. To attain food security, Malaysia has to focus on increased productivity by developing high yielding and environmentally adaptable seeds. The findings reveal that the respondents perceive food security is built on four important components; namely, accessibility, availability, stability and utilization. This finding would be useful information for policy makers and investors in their planning and decision-making.
\end{abstract}

Keywords: Food security, food value chain, seed industry, Malaysia. 


\section{Introduction}

Food security has been defined as availability at all times of adequate world food supplies of basic foodstuffs to sustain a steady expansion of food consumption and to offset fluctuations in production and prices (World Food Summit, 1974). Food and Agriculture Organization (FAO) expanded the food security concept in 1983 , by including the securing access to available supplies by vulnerable people and defined food security as ensuring that all people at all times have both physical and economic access to the basic food that they need. The concept state that the demand and supply side should be balanced in the food security equation. The world summit of 1996 held in Rome, Italy defined food security as "Food security exists when all people, at all times, have physical and economic access to sufficient, safe and nutritious food to meet their dietary need and food preferences for an active and healthy lifestyle" (Shaw, 2007).

Food security is considered differently depending on whether the focus is at the macro or the micro level. At the macro level, food security means that enough food has to be available to cover the whole population's nutritional requirements. At the micro level, for households and individuals, three conditions need to be considered: sufficient food at the macro level, stability in supply, and a regular access to food for all households and their members. Various studies emphasize food availability at the macro level by focusing on the market elements such as production inputs, labor, consumer goods and credit, quantities supplied and demanded, and prices. On these terms, food security is achieved if subsistence production and market supplies are sufficient to meet total household food requirements. However, in order to successfully provide food security to all citizens, two additional elements of the domestic food system have to be considered. First, individual households must be able to afford the food that is produced. Employment opportunities and how incomes are distributed play an important role here. The second element is food prices. Short-run food price fluctuations and shocks make low income households especially vulnerable to food insecurity (Timmer, 2000; Margaret, 1999).

Furthermore, food may be available globally but not all countries, households within countries, or individuals within households may have access to it. At the national level, persistent food insecurity is the result of development failure that prevents food-deficit countries from either acquiring food in the international markets or producing it themselves. However, even when sufficient food for the entire populations is available, food insecurity may persist. Poverty is often the culprit. The poor do not have adequate means to secure their access to food even when food is available in local or regional markets (Downing, 1998; Stamoulis, 1999).

Evidence from other countries such as the United States (Kinsey, 1994; Olson, 1997; and McDowell, 1997) and Myanmar (Kyaw, 2009) finds that there is a significant relationship between household food security and household socioeconomic and demographic characteristics, such as, annual income, household size, education, whether the household is headed by a single parent, employment status, presence of savings, and home ownership. Specifically, with regard to the issue of gender and food security, FAO has documented a strong inter-relationship (FAO, 1996). Women's contributions to the household play an important role in food security both in terms of production and nutrition. Furthermore, Davis (1982), Meade (1996), and McDowell (1997) find that income and food prices are major determinants of household food expenditures and that per capita income explains differences in the share of income spent on food.

In addition, a larger percentage of food-insecure individuals lived in households headed by a single female with children. Food-insecure individuals also usually lived in larger families 
than food-secure individuals. Household heads of food-insecure families were less likely than heads of food secure households to be high school graduates. In addition, a smaller percentage of food-insecure individuals than food-secure individuals were covered by health insurance. Although the economy of Myanmar is very different from that of Malaysia, some research on food security there is worth mentioning. Myanmar is self-sufficient in food and rice production at the national level.

Analyses of the drivers that will influence the food system over the next few decades have persuaded many people that we are entering a new period where rapidly rising demand and supply-side stressors threaten to increase food prices to levels that will increase hunger, malnutrition and may cause politico-economic disruption. What is the appropriate supply-side response to these challenges, and what role should research have in the natural and social sciences? One response to these challenges is often called sustainable intensification.Sustainable intensification argues first, that increased production must play at least some role in meeting the food security challenge of the next fifty years; second, that the vast majority of this increase must come from existing agricultural land; third, that increasing the sustainability of food production is of equal importance; and fourth, that we must consider a broad range of tools and production methods to achieve these goals (Tara \& Charles 2012).

Nonetheless, in the past, Malaysia did not really emphasize on seed production other than for rubber, oil palm and rice; so nowadays, the country relies mostly on imported seed to sustain the population's demand. Until 2012, Malaysia was importing $90 \%$ of its vegetables, $95 \%$ of its corn, and $100 \%$ of the melons consumed in the country. Consequently, in order to ensure a sufficient supply of quality seeds, and to successfully develop the seed industry in Malaysia, strategic areas have been identified to strengthen the industry. In 2011 as mentioned before, the National Agro-food Policy was approved which outlined Conducive Policy for the Development of the Seed Industry, focusing on the agro-food sectors development, by ensuring food supply, improving food processing, and by increasing high-value exports. Additionally, this policy aims to augment food production and the peoples' incomes while avoiding any food crisis in the country.

This question brought attention to the need for a business model to improve the growth of the seed industry in Malaysia, with the aim of providing insight and understanding of the industry, to aide policy makers in formulating the right policy; and, at the same time, attract investors to invest in the seed industry so that Malaysia can produce enough food to be self-sufficient and attain food security. In view of the food security issues above, it is important to understand the components of food value chain that influencing the food security issues. Therefore, the aim of this study is to identify the components of the food value chain that influence food security in regard to the seed industry in Malaysia.

\section{LITERATURE REVIEW}

\section{Factors Influencing Food Security}

In economics, vulnerability can be defined as a combination of exposure to risk and access to coping mechanisms to manage that risk. Attempts to develop theoretical frameworks about people's vulnerability to food security have expanded the recognition of sociological views about food security (and insecurity) as a "managed experience" (Radimer, et al 1990; Frankenberger et al, 1992). People are not victims of catastrophic events, rather they are "active participants in responding to risk in their everyday lives" (Coates et al, 2006). Support for this notion of food 
insecurity, as a managed process comes from cross-cultural evidence of orderliness to food insecurity experiences, in which households allocate and reallocate resources under conditions of scarcity. First, households express worry and uncertainty about food sources, then they begin substituting foods of insufficient quantity or inadequate quality, and finally, they resort to eating foods which are not socially acceptable or acquire foods through socially unacceptable methods or begin going without meals (Coates et al, 2006). There are many factors that determine food security and many studies about food security which have been done on different levels; such as a country or a household level. Among the factors are as follows:

\section{Food Price}

Arshad and Hameed (2010) examined the factors that affect price increases in food commodities and the implication they bring to food security in Malaysia. The initial factors that cause a food price crisis are the fundamentals that include: a decline in growth of agricultural production, hence, supply; a decline in global cereal stocks; and, an increase in food demand from emerging economies. The second cause of a food crisis is the systemic factors that include an underinvestment in agriculture and a lopsided policy towards export crops at the expense of domestic food supply. Third and fourth causes are an increase in bio-fuel demand and technical factors respectively. As a net food importer, all of these factors have affected Malaysia in terms of: first, a higher food import bill, where in 2008, Malaysia's food deficit increased to RM10.9 billion as compared with RM4.9 billion in 2000 . The second factor is an increase in the consumer price index affected by the recent global price change as a result of the currency market. The third implication was a short spell of social unrest in the midst of the price increase crisis. At that time, the author recommended increasing public funding for agriculture research and development to promote stability, growth and productivity through liberalization and deregulation.

\section{Population}

Most of the previous studies have focused on objective food security measures at the household level. Population is one of the factors that give impact to food security. At the household level, household size is the most important determinant of food security. James, Robert and Thomas (2013); Mitiku, Fufa \& Tadese (2012); Faridi \& Wadood (2010); Omotesho, Adewumi, Muhammad-Lawal \& Ayinde (2006); and Bashir, Schilizzi and Pandit (2012) in their studies of the determinants of food security, show that household size is significant and has a negative relationship to food security. This result or finding shows that an increase in household members will decrease food security within a household. On the other hand, household size, in relation to food insecurity, shows significant positive results (Gebre, 2012). At the country level, we can imply that the increase in population will decrease food security and vice versa.

\section{Climate Change}

Alam, Siwar, Murad and Toriman (2011) empirically investigated the phenomena of climate change; such as floods, natural disasters, pest attacks, droughts, plant disease and the timeline of crop cycles, against agriculture productivity change, crop choices and food security in Malaysia. The chosen crops were rice paddy production (main staple food), vegetables, fruit, beef, fish products, pork, mutton, chicken, eggs, ducks, and dairy products. They found that climate change 
had a negative impact on self-sufficiency and long term food security in Malaysia. Where, $64.1 \%$ of all surveyed farmers reported a decrease in the yield of rice paddy production due to climate change while $65.2 \%$ of them reported the same impact for other crops. They also gave the following suggestions to help agriculture farmers adapt to climate change problems. First is controlling the pattern of rainfall, sunshine and moisture levels. Second is protecting crops from excessive rainfall or sunshine and solving excessive water problems by improving shield resources and drainage. Third is the development of varieties of crops, and especially the development of rainfall and temperature tolerant plants and finding alternative crops and hybrids as a defensive approach. Fourth is to implement an alternative approach by changing the crop cycle and reducing crop cycle timing. The final suggestion was to provide weather forecasts and early warning systems to ensure the delivery of proper weather related information at the farm level.

\section{Foreign Worker}

A foreign worker is a person who is employed in a country, on a temporary basis, to which country; the person is not a citizen. Foreign workers are recruited by a company, recruitment agency or hired whilst they were job seeking in a country which was supplementing its workforce, for a limited term or to provide skills on a contractual basis (Mohamed, Ramendran SPR and Yacob, 2012). While, according to the Ecumenical Council for Corporate Responsibility (ECCR), the UN Migrant Workers Convention defines a migrant worker broadly as a person who is to be engaged, is engaged, or has been engaged in a remunerated activity in a State of which he or she is not a national.Kanapathy (2006) stated that migration has positive, negative or neutral effect and there is little empirical analysis on the impact of migrant workers on the Malaysian economy due to a lack of accurate data on contract migrant workers. However, several casual observations have been made according to the irregular migrations where there seems to be a high incidence of, and the visible evidence of, socio-political and security problems. These observations tend to highlight the negative impact of migrant workers on the economy. There are differences in crosscountry experiences which show, in some areas, that the immigrants have had a reasonably positive impact on economy, but it is important to note that the impact of immigrants on the local economy is depends on the magnitude and type of immigrants (Kanapathy, 2006).

\section{Innovation}

The rapid social, political and technological changes coupled with globalization, aborderless world and industrialization has changed the market environment. Some people predict that the changes taking place are just the beginning and there are more to come. These changes will provide opportunity for some companies and nightmares for others. As the process continues, some casualties are expected, some survivors, and a few successes. So, the ability to innovate is the key to a competitive advantage in this highly turbulent environment. Innovation has been recognised as one of the key factors that affect competitiveness. Although the benefits of innovation have been well recognized, innovation is still poorly understood. Definitions are often confused with invention. Innovation involves the exploitation of new ideas and the link between innovation and business performance had been proven to have a correlation (CBI/NatWest, 1997:17).Creating value through innovation is a new way of developing new products and processes that contribute to wealth but to be sustainable, a firm must begin to look for distinctive capabilities. Recently, it has become more important 
to identify these capabilities and build on them for future success. Companies have begun to compete with each other on the basis of who can be the fastest after realizing the benefits of technology. Therefore, innovation has become a tremendously important, competitive tool.

\section{The Sustainable Food Value Chain Development Paradigm}

A value chain is defined as the full range of activities that are required to bring a product or service from conception, through the different phases of production, delivery to final customers, and final disposal after use. In the context of food production, these activities include farm production, trade and support to get food commodities to the end-consumer (Kaplinsky and Morris, 2002).

Food value chains represent a business model in which producers and buyers of agricultural products form strategic alliances with other supply chain actors, such as aggregators, processors, distributors, retailers, and consumers, to enhance financial returns through product differentiation that advances social or environmental values. Partners in these business alliances recognize that creating maximum value for their products depends on interdependence, collaboration, and mutual support. The food value chain model is gaining traction because it responds to agricultural and food industry consolidation that has placed intense market pressure on small and mid-sized farmers. The model also describes how small and mid-sized farm operators band together and respond to food-industry market trends, which include a growing consumer demand for food products differentiated by values-related product claims such as "local," "regional," or "organic" food. Local food sales were approximately $\$ 5$ billion in 2008 , with the majority of these sales moving through supermarkets, restaurants, food-service institutions, and other wholesale marketing channels (Low, 2011), while sales of organic food and beverages in the United States reached nearly \$27 billion in 2010, up from only \$1 billion two decades earlier (Industry Statistics, 2012).

A food value chain consists of all the stakeholders that participate in the coordinated production and value adding activities that are needed to make food products. One, the relationships between value-chain actors facilitates the ongoing movement of food from farm to table. Two, such relationships are governed by shared operational and mission values. Three, the operational design, set of values, and ultimate success of a food value chain are conditioned by a multitude of external factors, including market demand, availability of support services and physical assets, access to capital, and the policy environment.Food value chains are most effective when the enterprises involved in the value chain can agree upon a set of mission values, such as farm viability, farmland preservation, healthy food access, and sustainable production practices, and a set of shared operational values, such as accountability, long-term commitment, open and ongoing communication, and transparency, and use these shared mission and operational values as a means to differentiate and add value to the products they are offering to their customers.

\section{RESEARCH METHODOLOGY}

The field research undertaken in this study involved data collection by 12 semi-structured faceto-face interviews of seed experts. Collected data went through a process before analysis. The main process was transcription carried out by the researcher. This process was to ensure 
consistency and accuracy; it began with transcription, follow by thematic coding and content analysis. Coding was necessary for efficient analysis and through it several replies may have been shortened. The population and sample in this study consists of members of the National Seeds Association Malaysia. The sample size of this qualitative research is small, but it provides an extensive amount of information from the comments of the respondents (Maxwell, 1996). These descriptions provide details of the context and meaning of events and situations for those involved and those investigating (Geertz, 1983). By pursuing a multiple case study design, the samples should share the same characteristics across all cases (Farquhar, 2012). Thus, in this study, the sample size of 12 selected experts was divided into three clusters, namely plant breeders, traders or managers and seed production experts. Each cluster was represented by 4 members.

\section{RESULTS}

This section discusses the findings of the research data in relation of the research question: What are the components of the food value chain that influence food security in Malaysia? There were three themes generated in this analysis to answer the research question. Firstly, perception of food security, secondly, status of food security in Malaysia associated with sustainable intensification and, lastly, components of the food value chain.

\section{Perception of Food Security}

The challenge of food security must be addressed immediately. Achieving a sufficient food supply is a global challenge and a complex sustainable development issue to most of the developing countries. Accordingly, of all the twelve respondents, four of them claimed that food security has been defined as existing food, to all people, at all times, as listed below:

\section{P 1: Verbatim 1.docx - 1:3 (29:30)}

...to my knowledge, food security can be said adequacy of food by all people at all times to get active and healthy life...

\section{P 2: Verbatim 2.docx - 2:2 (29:29)}

... food security exists when all people, at all times, have physical and economic access to sufficient, safe, and nutritious food for a healthy and active life.

\section{P 10: Verbatim 10.docx - 10:2 (59:59)}

...food security as existing when all people, at all times, have physical and economic access to sufficient, safe and nutritious food that meets their dietary needs and food preferences for an active and healthy life.

\section{P 11: Verbatim 11.docx - 11:1 (47:47)}

...availability at all times of adequate world food supplies of basic foodstuffs to sustain a steady expansion of food consumption and to offset fluctuations in production and prices.

The remaining five respondents perceived that the most important item was to have physical and economic access to sufficient, safe and nutritious food for a healthy and active life. The following quotations show their perception of food security: 


\section{P 6: Verbatim 6.docx - 6:2 (42:42)}

So all nation have to make sure food supply are in order and enough, this is part of the social economic...

\section{P 7: Verbatim 7.docx - 7:1 (41:41)}

To me food security mean there are enough food for everyone at any time, any place at a affordable price.

\section{P 8: Verbatim 8.docx - 8:1 (41:41)}

As for my understanding, food security means we have enough for the nation whenever that is need.

\section{P 9: Verbatim 9.docx - 9:1 (40:40)}

Food security to my layman interpretation mean there are enough food for every one at any time, any place at a affordable price.

\section{$P$ 12: Verbatim 12.docx - 12:13 (43:43)}

...you know hungry people are angry people, it might led to riot if that is not enough food. To me food security mean, we have enough food for everyone any time any place.

Even so, two of them said that food security was when all people get enough food:

\section{P 3: Verbatim 3.docx - 3:8 (30:30)}

Food security is also an important element of poverty, and embraces production, supply, processing, distribution and market access.

\section{P 5: Verbatim 5.docx - 5:10 (30:30)}

...is important to make sure that the country is in stable condition for the economy and also for their citizen.

\section{Status of Food Security in Malaysia}

In these responses, respondents perceive that there are many factors that affect food security to ensure sufficient levels of food in Malaysia. Good agricultural practices with good agricultural input will help to improve productivity and harmonize supply and demand. Currently, the food bill in Malaysia is causing a deficit. The country has to produce more food locally to ensure selfsufficiency. The following shows that the status of food security in Malaysia is:

\section{P 1: Verbatim 1.docx - 1:14 (35:35)}

... in Malaysia will face a dangerous situation where the supply of the country is insufficient to meet the needs all residents.

Accordingly, sustainable development, for food security and sustainable food systems, is a food system that ensures food security and nutrition for all in such a way that the economic, social and environmental bases to generate food security and nutrition of future generations are not compromised. Sustainable agricultural development contributes to achieving food security and nutrition.

In relation to sustainable intensification, its association with the status of food security in Malaysia was stated: 


\section{P 4: Verbatim 4.docx - 4:2 (30:30)}

...sustainable agricultural development is agricultural development that contributes to improving resource efficiency, strengthening resilience and securing social responsibility of agriculture and food systems in order to ensure food security and nutrition for all, now and in the future.

\section{P 5: Verbatim 5.docx - 5:3 (40:41)}

The sustainable food value chain development paradigm starts from the premise that food insecurity is foremost a symptom of poverty. Households that have sufficient financial resources at all times create the effective demand that drives the supply of food.

\section{Components of the Food Value Chain}

With regard to food security being a widely debated issue, this topic encompasses issues built mainly on four dimension; food availability, food stability, food accessibility and food utilization. Food availability addresses the supply side of food security and is determined by food production, stock levels, trade and other factors. Stability reflects the presence of the other three elements over time, so, sudden economic, climatic or other shocks or cyclical events such as seasonal food insecurity affect the stability of supply. Access to food includes household incomes and expenditures, markets, food prices and food utilization which relates to the body's ability to make use of food nutrients. Utilization also includes the need for sufficient energy and nutrients, as well as, good care and feeding practices, safe food preparation, dietary diversity, food distribution within households and individual health status. Some respondent remarked:

\section{P 2: Verbatim 2.docx - 2:11 (34:35)}

The components of food value chain that influences the food security including Food availability, food utilization and also food stability...

\section{P 3: Verbatim 3.docx - 3:12 (35:36)}

The major components of food security are firstly, availability of food is determined by the level of food production, stock levels and net trade. Secondly, food utilization is commonly understood as the way the body makes the most of various nutrients in the food. Next is food accessibility and lastly is food stability.

\section{P 4: Verbatim 4.docx - 4:13 (34:35)}

Agricultural development is key to food security in several ways, contributing to food availability, access and stability and - through the diversity of foods produced - food utilization.

\section{Summary of the Results}

From the quotations above, it can be summarized that each of the participants perceived food security exists when all people, at all times, have physical and economic access to sufficient, safe and nutritious food to meet their dietary need and food preferences for an active and healthy lifestyle. The challenge of food security must be addressed immediately. Achieving a sufficient food supply is a global challenge and a complex sustainable development issue to most of 
developing countries. With regard to food security in Malaysia, the participants were asked about the status of food security in Malaysia in association with sustainable intensification. They believed that for our nation to have a peaceful and stable life, we need to provide people with enough food at all times.

As for the supply, we cannot depend solely on imports since the food bill in Malaysia is causing a deficit. We have to produce more food locally and ensure self-sufficiency. As such, respondents suggested that we address the problem immediately. The population has increased to 32 million and will continue to increase; so too, the demand for food will naturally increase. In term of components of the food value chain, all respondents looked at four factors; accessibility, availability, stability and utilization. To increase productivity by increasing the cultivation area is not practical as land is decreasing due to an increase in population.

The other alternative is to look at good production methods with the help of technology and good agricultural input. Agricultural input includes fertilizers, chemicals, knowledgeable workers and productive seed. Seed is fundamental for the entire chain. Accordingly, a detailed breakdown of the interview responses for this research question is provided in Table 1.

Table 1: Summary of the Results

\begin{tabular}{|c|c|c|c|c|}
\hline Themes & Sub-themes & Codes & $\begin{array}{c}\text { Respondents } \\
\text { (Verbatim) }\end{array}$ & $\begin{array}{l}\text { Industry/ } \\
\text { Background }\end{array}$ \\
\hline $\begin{array}{l}\text { Perceptio } \\
\mathrm{n} \text { of Food } \\
\text { Security }\end{array}$ & $\begin{array}{l}\text { - Existing Food } \\
\text { - Enough Food } \\
\text { - Most Important } \\
\text { Item }\end{array}$ & PoFS & $\begin{array}{c}1,2,10 \& 11 \\
6,7,8,9 \& 12 \\
3,4 \& 5\end{array}$ & $\begin{array}{c}\text { Plant Breeder (4), } \\
\text { Production Expert } \\
\text { (4) } \\
\& \\
\text { Trader (4) }\end{array}$ \\
\hline $\begin{array}{l}\text { Status of } \\
\text { Food } \\
\text { Security in } \\
\text { Malaysia }\end{array}$ & $\begin{array}{l}\text { - Sustainable } \\
\text { Intensification }\end{array}$ & Status & $1,4 \& 5$ & $\begin{array}{l}\text { Plant Breeder (2), } \\
\text { Production Expert } \\
\text { (1) }\end{array}$ \\
\hline $\begin{array}{c}\text { Compone } \\
\text { nts of } \\
\text { Food } \\
\text { Value } \\
\text { Chain }\end{array}$ & $\begin{array}{l}\text { - Availability } \\
\text { - Stability } \\
\text { - Accessibility } \\
\text { - Utilization }\end{array}$ & CoFVC & $2,3 \& 4$ & $\begin{array}{l}\text { Plant Breeder (1), } \\
\text { Production Expert } \\
\text { (2) }\end{array}$ \\
\hline
\end{tabular}

A summary of the findings is presented in Figure 1 below to show the connection between the food securities within the context of this particular research question. 


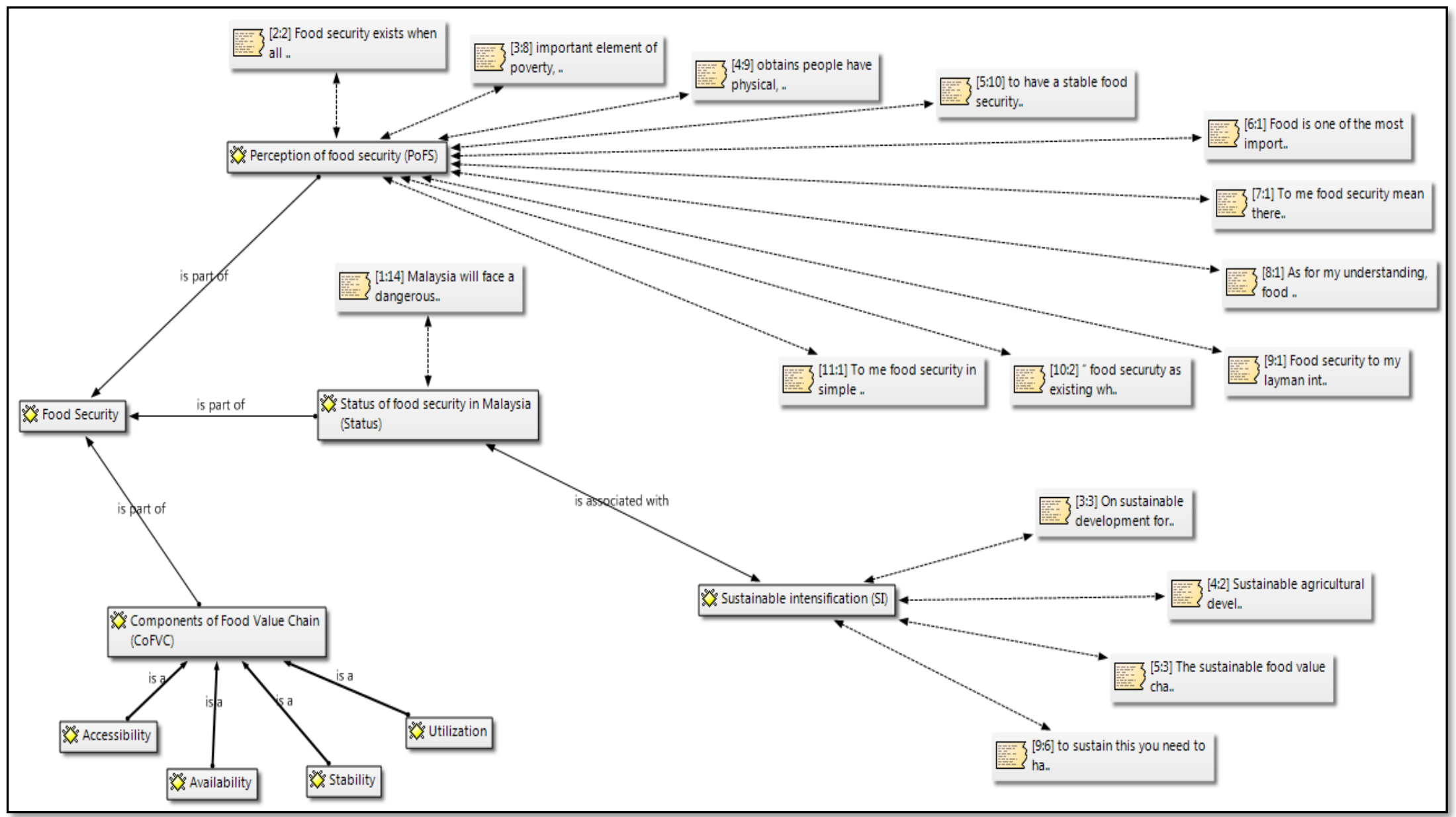

Figure 1: The components of the food value chain that influence food security in regard to the seed industry in Malaysia 
INTERNATIONAL JOURNAL OF ACADEMIC RESEARCH IN BUSINESS AND SOCIAL SCIENCES

Vol. 8, No. 12, Dec, 2018, E-ISSN: 2222-6990 @ 2018 HRMARS

\section{DISCUSSION AND CONCLUSION}

The seed industry in Malaysia is at an early phase of development (Melor, 2003) due to a lack of participation and an undeveloped seed industry (Chin et al., 2006), hence, literature from which to draw hypotheses is limited and it is difficult to even assemble a meaningful sample for data collection. Such being the case, to seek a more in-depth understanding and to hear first hand information, the best approach is through a qualitative research technique (McDonald, 1985). Qualitative studies are theories built from research by identifying patterns and broad relationships in the rich, descriptive data (Pidgeon \& Henwood, 2004). In addition, this research adopts Yin's (2003) definition of a case study as an empirical inquiry that investigates a contemporary phenomenon within its real-life context, when the boundaries between phenomenon and context are not clearly evident, and in which, multiple sources of evidence are used. The findings of this study pertain to the components in the food value chain that influence food security in the Malaysian seed industry.

The findings reveal that the respondents perceive food security is built on four important dimensions; namely, accessibility, availability, stability and utilization. Based on the respondents' view, Malaysia's food security status is not at the most healthy level since respondents noted the import bill remains at an all time high causing an urgent need to address this problem. Most feel an increase in agriculture productivity is the most likely recommended option. Agriculture productivity depends on agriculture input of which, the seed is the fundamental component of the food value chain, hence, respondents suggested intensifying the seed industry to increase productivity.

According to this study, all of the respondents understood the definition of food security and also shared the view that food security in Malaysia is rather weak. To achieve the goal of food security, the entire group of respondents suggested the issues of food security must be addressed immediately. These issues demand changes in agricultural practices and there is urgency for sustainable agriculture. Sustainable agricultural development is one of the most powerful tools for higher productivity. Higher productivity in agriculture is fundamentally dependent on good seed, since it is the most important input component for productive agriculture (Singh, Asokan and Asopa, 1990). It is estimated that the direct contribution of high quality seed alone could increase productivity by twenty per cent (Singh, Asokan and Asopa, 1990). Moreover, seeds are the fundamental sources of productivity of the total supply chain, where seed contributed the least in total cost of food production, in comparison to other inputs such as the cost of labour, land, chemicals or fertilizer. As such, to improve productivity Malaysia should invest more heavily in the development of good seed, where the supply of good seed is limited and $90 \%$ of the seed supplies are imported (Melon, 2003). Further more. it was noted, the seed industry in Malaysia was not well developed nor as intensive as Europe, American, China or India (Chin et al., 2006).

The seed industry has a unique future and its development and sustained growth require assets, that include both tangible assets and intangible assest. In today's highly competitive market, customers' preferences are constantly changing which requires firms to have a well planned strategy to remain competitive and sustain growth (Porter, 1996). Sustained growth of a industry can not be attribute to industry conditions alone, a clear understanding of company strengths and industry framework are required. 
INTERNATIONAL JOURNAL OF ACADEMIC RESEARCH IN BUSINESS AND SOCIAL SCIENCES

Vol. 8, No. 12, Dec, 2018, E-ISSN: 2222-6990 C 2018 HRMARS

\section{REFERENCES}

Alam, M. M., Siwar, C., Murad, M. W., \& Toriman, M. E. (2011). Farm level achievement of climate change, agriculture and food security issues in Malaysia. World Applied Science Journal, 14, 431-442.

Arshad, F. M., \& Abdel Hameed, A. A. (2010). Global Food Prices: Implications to Food Security in Malaysia, CRRC Consumer Review, 1(1), 21-38.

Bashir, M. K., Schilizzi, S., \& Pandit, R. (2012). Food security and its determinants at thecrossroads in Punjab, Pakistan. (Working Paper 1206), School of Agricultural and

Resource Economics, University of Western Australia, rawley, Australia.

Coates, J., E. A. Frongillo, B. L. Rogers, P. Webb, P. E. Wilde, and R. F. Houser. (2006).

Commonalities in the Experience of Household Food Insecurity across Cultures: What Are Measures Missing?. Journal of Nutrition, 136.

Davis, B. (1982). Hunger in Canada. Agriculture and Human Values, 11(4), 50-57.

Downing, T. E. (1998). Assessing socioeconomic vulnerability to famine: Frameworks, concepts, and applications. FEWS Working Paper (2.1). USAID, Famine Early Warning System Project, Washington, $D C$.

FAO. (1996). Rome declaration on world food security, World Food Summit. Rome: $\quad$ FAO.

Faridi, R., \& Wadood, S. N. (2010). An assessment of household food security in Bangladesh. The Bangladesh Development Studies, XXXIII, 97-111.

Farquhar, S. E. (2012). Gifted Children in the Early Years: Feedback on a Survey of the Education of Gifted Children Under 8 Years of Age. Retrieved from,

http://www.childforum.com/childcare-a-teaching/gifted-young-children/381-

giftedchildren-in-the-early-years-feedback-on-a-survey-of-the-education-of-gifted-

childrenunder-8-years-of-age.html

Frankenberger, T. (1992). Indicators and Data Collection Methods for Assessing Household Food Security in S. Maxwell and T. Frankenberger (eds), Household Food Security: Concepts, Indicators, and Measurements: A Technical Review. New York and Rome: UNICEF and IFAD.

Gebre, G. G. (2012). Determinants of food insecurity among households in addis ababa city, Ethopia. Interdisciplinary Description of Complex System, 10, 159-173. http://dx.doi.org/10.7906/indecs.10.2.9 
INTERNATIONAL JOURNAL OF ACADEMIC RESEARCH IN BUSINESS AND SOCIAL SCIENCES Vol. 8, No. 12, Dec, 2018, E-ISSN: 2222-6990 C 2018 HRMARS

Geertz, C. (1983). Local Knowledge: Further Essays in Interpretative Anthropology. New York: Basic Books.

Kanapathy, V. (2006). Migrant workers in Malaysia: An overview. Paper presented at the Workshop on an East Asian Cooperation Framework for Migrant Labour, Kuala Lumpur.

Kaplinsky, R., M. Morris and J. Readman (2002), "The Globalisation of Product Markets and Immiserising Growth: Lessons from the South African Furniture Industry", World Development, 30(7), 1159-1178.

Kinsey, J. D. (1994). Food and families' socioeconomic status. Journal of Nutrition, 124, 18781885.

Kyaw, D. (2009). Rural households' food security status and coping strategies to food insecurity in Myanmar. In Institute of Development Economics Japan External Trade Organization. Assessing prospects for improving food security and nutrition, V.R.F. series, no 444. FNA/ANA, 25, 5-9.

Margaret, S. A. (1999). Measuring food insecurity and hunger in the United States: Development of a national benchmark measure and prevalence estimates. The Journal of Nutrition, 129(2), 510516. https://doi.org/10.1093/in/129.2.510S

Maxwell, J. A. (1996). Qualitative Research Design: An Interactive Approach. Thousand Oaks, CA: Sage Publications.

McDowell, D. R. (1997). Food expenditures and socioeconomic characteristics: Focus on income class. American Journal of Agricultural Economics, 79(5), 1444.

Melor, R. (2003). Varieties, Improvement of Solanaceous Vegetable: Current Achievement, Constraint and Strategies, 3rd National Seed Symposium, University Putra Malaysia, Kuala Lumpur, Malaysia, 51-57.

Mitiku, A., Fufa, B., \& Tadese, B. (2012). Empirical analysis of determinants of rural households food security in Southern Ethiopia: The case of Shashemene district. Basic Research Journal of Agricultural Sciene and Review ISSN, 1, 132-138.

Mohamed, R. K. M. H., Ramendran, S. P R. C., \& Yacob, P. (2012). The impact of employment of foreign workers: Local employability and Trade Union roles in Malaysia. International Journal of Academic Research in Business and Social Sciences October 2012, 2(10).

Olson, C. M. (1997). Factors contributing to household food insecurity in a rural upstate New York county. Fam. Econ. Nutr., 10, 2-17. 
Omotesho, O. A., Adewumi, M. O., Muhammad-Lawal, A., \& Ayinde, O. E. (2006). Determinants of food security among rural farming households in Kwara State, Nigeria. African Journal of General Agriculture, 2, 7-15.

Pidgeon, N. \& Henwood, K. (1997). Using grounded theory in psychological research, in N. Hayes (ed.) Doing Qualitative Analysis in Psychology. Hove: Psychology Press.

Porter, M. E. (1996). What is Strategy, Harvard Business Review, 14(1): 179-191. Radimer, K. L., Olson, C. M. \& Campbell, C. C. (1990). Development of indicators to assess hunger. Journal Nutrient,120, 1544-1548.

Shaw D. J. (2007) World Food Summit, 1996. In: World Food Security. Palgrave Macmillan, London https://doi.org/10.1057/9780230589780 35

Singh, G., Asokan, S. R. \& Asopa, V. N. (1990). Seed Industry in India - A Management Perspective. Oxford \& IBH Publishing Co. (Pvt.) Ltd., New Delhi.

Stamoulis, K. (1999). A conceptual framework for national agricultural, rural development, and food security strategies and policies. ESA Working Paper, 03-17, FAO.

Tara, H. \& Charles, G. (2012). The State of Food Insecurity in the World, Journal of Food and Agriculture, 87(8), 39-40.

Timmer, C. P. (2000). The macro dimensions of food security: Economic growth, equitable distribution, and food price stability. Food Policy, 25(4), 283-295.

World Food Summit (1974). United Nations. New York, 1975. Convened by the General Assembly of the United. www.eclac.cl/cumbres/.../FAORLC-41001WorldFoodSummit.doc

Yin, R. K. (2003). Applications of Case Study Research (2nd ed.). United State: Sage Publications. 